\title{
Familial Mediterranean fever in Lebanon: mutation spectrum, evidence for cases in Maronites, Greek orthodoxes, Greek catholics, Syriacs and Chiites and for an association between amyloidosis and M694V and M694I mutations
}

\author{
Issam Mansour ${ }^{1}$, Valérie Delague ${ }^{1}$, Cécile Cazeneuve $^{2}$, Catherine Dodé $^{3}$, Eliane Chouery ${ }^{1}$, \\ Christophe Pêcheux ${ }^{3}$, Myrna Medlej-Hashim ${ }^{1}$, Nabiha Salem ${ }^{1}$, Loubna El Zein ${ }^{1}$, \\ Isabelle Levan-Petit ${ }^{4}$, Gérard Lefranc ${ }^{5}$, Michel Goossens ${ }^{2}$, Marc Delpech ${ }^{3}$, Serge Amselem², \\ Jacques Loisel et ${ }^{1}$, Gilles Grateau ${ }^{3}$, André Mégarbane ${ }^{1}$ and Roger Naman ${ }^{1}$ \\ ${ }^{1}$ Unité de Génétique M édicale, Université Saint Joseph, Faculté de Médecine, Beirut, Lebanon; ${ }^{2}$ Laboratoire de \\ Biochimie Génétique, Centre Hospitalier Henri Mondor, Créteil; ${ }^{3}$ Universi té Paris V, Laboratoire de Biochimie et \\ Génétique Moléculaire, Institut Cochin de Génétique M oléculaire, Paris; ${ }^{4}$ Laboratoire Cytokines, ESA CN RS6031, \\ IBM IG, Poitiers; ${ }^{5}$ Laboratoire d'Immunogénétique Moléculaire, UPR 1142 CNRS, Université Montpellier II, France
}

Seventy-nine unrelated Lebanese patients were tested for 15 mutations in the MEFV gene: A761H, A744S, V726A, K695R, M694V, M694I, M694del, M6801 (G $\rightarrow$ C), M680I (G $\rightarrow$ A) in exon 10, F479L in exon 5, P369S in exon 3, T267I, E167D and E148Q in exon 2, using PCR digestion, ARMS, DGGE and/or sequencing. Mutations were detected in patients belonging to all communities, most interestingly the Maronite, Greek orthodox, Greek catholic, Syriac and Chiite communities. The most frequent mutations are M 694V and V726A (27\% and $20 \%$ of the total alleles respectively). M694I, E148Q and M680I mutations account respectively for $9 \%, 8 \%$ and 5\%. Each of the K695R, E167D and F479L mutations was observed once and all the remaining mutations were not encountered. Of the alleles $33 \%$ do not carry any of the studied mutations. The mutation spectra, clinical features and severity of the disease differed among the Lebanese communities. The genotype-phenotype analysis showed a significant association $(P<0.001)$ between amyloidosis and the presence of mutations at codon 694 in exon 10 (both M694V and M694I). None of the patients carrying other mutations developed amyloidosis. European Journal of Human Genetics (2001) 9, 51-55.

Keywords: Familial Mediterranean fever; M EFV gene; Lebanese

\section{Introduction}

Familial Mediterrannean fever (FMF) is an autosomal recessive disorder characterised by recurrent attacks of fever of $\left(38-40^{\circ} \mathrm{C}\right)$ and painful episodes of sterile serositis that involves typically the peritoneum, pleura and/or synovia. ${ }^{1-4}$ Patients may also develop erysipelas-like erythema and less frequently amyloidosis that may affect several organs, particularly the kidney, leading to end-stage renal failure. ${ }^{1,2}$

Correspondence: Dr Issam Mansour, Hôtel Dieu de France Hospital, Boulevard Adib Ishac, BP: 166830, Beirut, Lebanon. Tel:

+961 1615300/400; Fax: +961 1615295; E-mail: CTSHD@cyberia.net.Ib

Received 10 January 2000; revised 23 August 2000; accepted

7 September 2000
The gene is responsible for the disease (MEFV) is located on the short arm of chromosome $16^{5,6}$ and is made up of 10 exons. Up to the present, 17 mutations that affect the MEFV gene have been found in Mediterranean populations, mainly Jews, Armenians, Turks, Arabs and Italians. ${ }^{3,7-19}$ A few patients have been al so reported outside the Mediterranean

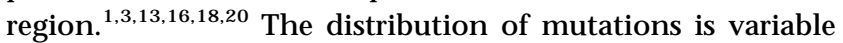
among populations but the M694V, V726A, M694I and M680I, account for over $80 \%$ of mutations. ${ }^{1,5,8,12,20,21}$

Since the early 1950s, FMF patients have been reported in the Lebanese population, ${ }^{12}$ which is a mosaic of 18 religious communities, mainly Maronite, Sunnite, Chiite, Druze, Greek orthodox, Greek catholics, Syriac and Armenian. 
The MEFV gene mutations had never been assessed in patients belonging to these communities. The aim of the present study is to determine the spectrum of MEFV mutations, compare their distribution in the different communities and analyse the phenotype-genotype relationship.

\section{Subjects and methods Patients}

Seventy-nine individuals from unrelated Lebanese families have been analysed. The diagnosis of FMF was made according to established clinical criteria (Sohar and Livneh classifications). ${ }^{22,23}$ Diseases sharing clinical features with FMF were ruled out as follows:

(1) Rheumatoid arthritis by the lack of joint deformity and the short and spontaneous resolution of the joint findings,

(2) Behçet's disease according to the criteria of the Japanese Research Committee, ${ }^{24}$ and

(3) the hyperimmunoglobunemia syndrome by IgD titration lower than $100 \mathrm{U} / \mathrm{ml}$.

The severity scores were evaluated referring to the Tel Hashomer classification. ${ }^{23}$ However, a high number of patients was diagnosed recently or was non-compliant to the colchicine treatment. For this reason, we calculated the severity score, without taking into consideration the colchicine dosage.

Patients belonged to both Moslem and Christian communities; Moslems were Sunnite, Shiite or Druze, and Christians were Maronite, Greek orthodox, Greek catholic, Syriac or Armenian.

\section{IgD measurement}

The IgD blood levels were determined using a new sensitive ELISA method as described elsewhere. ${ }^{25}$

\section{Mutation analysis}

As a first step, the PCR restriction-digestion, DGGE and sequencing methods were used sequentially on only 30 patients. Four different mutations were detected by these three methods (M694V, M694I, M680I, V726A). For sequencing, exon 10 was amplified using the 5'-GAGGTGGAGGTTGGAGACAA-3' and 5'-AGAGCAGCTGGCGAATGTAT-3' primers and analysed on an $A B I 377$ sequencer (Perkin Elmer, Applied Biosystems, Foster City, CA, USA). Sequencing was performed in both reverse and forward directions. Using DGGE, we studied fragment $10 \mathrm{~A}$ of exon 10 as described earlier. ${ }^{17} \mathrm{Next}$, the PCR restriction-digestion method was exclusively used for all patients and was extended to the other mutations: M694V, M680I, V726A, R761H, P369S, T267I, E167D and E148Q. The A744S, K695R and F479L mutation s were detected by the ARM S method. The deltal 692 and deltaM 694 were detected by a PCR-electrophoresis assay.
Primers, restriction enzymes and DNA fragments used for mutation analysis are listed in Tablel.

\section{Data analysis}

The frequency of mutation was estimated relatively to the total number of alleles. Only one allele was counted in patients homozygous by descent. The genotype-phenotype correlation was cal culated by the $\chi^{2}$ test with Yates's correction. Exact $P$ values were corrected to avoid a type I error. The statistical significance was determined by a $\mathrm{P}$ value $<0.01$. The M694V/M694V, M694V/M 694I and M 694I/M 694I genotypes were correlated to clinical features separately then compared among them. These three genotypes were also considered as one group homozygous for a mutation at the 694 codon of exon 10.

\section{Results}

Mutations were detected in patients belonging to heterogeneous religious origins. Of the patients $37 \%$ have a positive family history for the disease and consanguinity was observed for $33 \%$ of the patients; $96 \%$ of patients had fever, $94 \%$ abdominal pain, $54 \%$ thoracic pain, $46 \%$ arthritis, $10 \%$ skin involvement and $8 \%$ amyloidosis. The mean onset of the disease was relatively high (17years), and the sex ratio male/female was calculated at 1.5. Comparison of the frequencies among the different communities showed that Moslem patients had an earlier onset and frequency of arthritis twice as high as FMF-Christian patients, and that patients with amyloidosis belong exclusively to the Druze, Chiite and Armenian groups.

Mutation analysis showed that the 15 tested mutations account for $67 \%$ of the total alleles $(n=143)$, and 45 alleles (33\%) were tested negative. The M694V mutation is the most frequent, followed by the V726A, M 694I, E148Q and M680I mutations (Table2). However, a high heterogeneity was observed when the distribution was analysed by religious groups. The most significant differences concerned the frequencies of alleles testing negative for all mutations, and alleles positive for the M694V and M694I mutations. Whereas in Druze and Syriac patients all alleles were mutation positive, $75 \%$ of alleles (12/16) in Maronites tested negative. The M $694 \mathrm{~V}$ mutation accounts for $50 \%$ and $83 \%$ in Chiites and Armenians respectively, but was absent in Druzes, the Greek orthodox, Greek catholics and Maronites. The M694I mutation accounts for $56 \%$ in Druzes but was absent in Sunnites, Greek catholics and Syriacs.

When the genotype was correlated to clinical features, we observed that the highest severity scores were observed in patients carrying the M $694 \mathrm{~V}$ mutation. The mean severity score, without the colchicine dosage criteria, was found to be equal to 8 in M694V homozygous patients and is at least 2 points higher than the scores observed among FM $F$ patients homozygous for the other mutations (Table3). A higher mean score was also observed among M694V/M 694I heterozygous (Table3). The statistical analysis showed that only the 
Table 1 Primers, restriction enzymes and DNA fragment profiles used for mutation analysis

\begin{tabular}{|c|c|c|c|c|}
\hline Mutation & Primers & $\begin{array}{l}\text { Restriction } \\
\text { enzymes }\end{array}$ & Profile (in & $\begin{array}{l}\text { base pairs) } \\
\text { Mutant }\end{array}$ \\
\hline M694V & $\begin{array}{l}\text { Forward 5'-GAGGTGGAGGTTGGAGACAA-3' } \\
\text { Reverse: 5'-AGAGCAGCTGGCGAATGTAT-3' }\end{array}$ & $\mathrm{HpH} 1$ & 166-109 & 157-109-9 \\
\hline V726A & $\begin{array}{l}\text { Forward: 5'-TATCATTGTTCTGGGCTC-3' } \\
\text { Reverse: 5'-CTCCGTACTTCCTCCTCT-3' }\end{array}$ & Alu I & $315-154-129-67$ & 257-154-129-67-58 \\
\hline M680I & $\begin{array}{l}\text { Forward: 5'-TATCATTGTTCTGGGCTC-3' } \\
\text { Reverse: 5'-CTCCGTACTTCCTCCTCT-3' }\end{array}$ & Hinf I & $541-123$ & 664 \\
\hline E148Q & $\begin{array}{l}\text { Forward: 5'-AACTTTAATATCCAAGGGGATTC-3' } \\
\text { Reverse: 5'-TTCTCTGCAGCCGATATAAAGTA-3' }\end{array}$ & Ava I & 221-190-128-121-69-42 & $290-190-128-121-42$ \\
\hline E167D & $\begin{array}{l}\text { Forward: 5' AACTTTAATATCCAAGGGGATTC-3' } \\
\text { Reverse: 5'-TTCTCTGCAGCCGATATAAAGTA-3' }\end{array}$ & Dra II & $268-202-179-83-47$ & $447-202-83-47$ \\
\hline T267I & $\begin{array}{l}\text { Forward: 5'-AACTTTAATATCCAAGGGGATTC-3' } \\
\text { Reverse: 5'-TTCTCTGCAGCCGATATAAAGTA-3' }\end{array}$ & MspA1l & 453-184-155 & $453-339$ \\
\hline P369S & $\begin{array}{l}\text { Forward: 5'-GAAGAGCCCGGGAAGCCTGAGC-3' } \\
\text { Reverse: 5'-TTGGGAAAATGAAGTAAGGCCC-3' }\end{array}$ & Sac I & 252 & $228-24$ \\
\hline $\begin{array}{l}\text { I692del\& } \\
\text { M694del }\end{array}$ & $\begin{array}{l}\text { Forward: 5'-GAGGTGGAGGTTGGAGACAA-3' } \\
\text { Reverse: 5'-GACGCCTGGTACTCATITT-3' }\end{array}$ & $\begin{array}{l}\text { No } \\
\text { digestion }\end{array}$ & 135 & 132 \\
\hline M694I & $\begin{array}{l}\text { Common: 5'-TATCATTGTTCTGGGCTC-3' } \\
\text { Normal: 5'-CTGGTACTCATTTTCCTTC-3' } \\
\text { Mutant: 5'-CTGGTACTCATITTCCTIT-3' }\end{array}$ & $\begin{array}{l}\text { No } \\
\text { digestion }\end{array}$ & $\begin{array}{l}\text { Amplification with } \\
\text { normal primer }\end{array}$ & $\begin{array}{l}\text { Amplification with } \\
\text { mutant primer }\end{array}$ \\
\hline A744S & $\begin{array}{l}\text { Common: 5'-GAGGTGGAGGTTGGAGACAA-3' } \\
\text { Normal: 5'-CCAGAGAAAGAGCAGCTGGC-3' } \\
\text { Mutant: 5'-CCAGAGAAAGAGCAGCTGGA-3' }\end{array}$ & $\begin{array}{l}\text { No } \\
\text { digestion }\end{array}$ & $\begin{array}{l}\text { Amplification with } \\
\text { normal primer }\end{array}$ & $\begin{array}{l}\text { Amplification with } \\
\text { mutant primer }\end{array}$ \\
\hline F479L & $\begin{array}{l}\text { Common: 5'-CCACCTCTTATCCACCTCC-3' } \\
\text { Normal: 5'-CCTCCAGTGAGGCCACAAAG-3' } \\
\text { Mutant: 5'-CCTCCAGTGAGGCCAGAAAC-3' }\end{array}$ & $\begin{array}{l}\text { No } \\
\text { digestion }\end{array}$ & $\begin{array}{l}\text { Amplification with } \\
\text { normal primer }\end{array}$ & $\begin{array}{l}\text { Amplification with } \\
\text { mutant primer }\end{array}$ \\
\hline
\end{tabular}

Table 2 Allele frequency ${ }^{1}$ among the Lebanese communities

\begin{tabular}{|c|c|c|c|c|c|c|c|}
\hline & & M694V \% & V726A \% & M694I \% & E148Q \% & M680I \% & None $\%$ \\
\hline Total alleles & $\mathrm{n}=143$ & 27 & 20 & 9 & 8 & 5 & 33 \\
\hline $\begin{array}{l}\text { Total Moslem² } \\
\text { Total Christian² }\end{array}$ & $\begin{array}{l}n=75 \\
n=64\end{array}$ & $\begin{array}{l}32 \\
22\end{array}$ & $\begin{array}{l}19 \\
22\end{array}$ & $\begin{array}{r}12 \\
6\end{array}$ & $\begin{array}{l}9 \\
5\end{array}$ & $\begin{array}{l}5 \\
5\end{array}$ & $\begin{array}{l}25 \\
41\end{array}$ \\
\hline $\begin{array}{l}\text { Druze }{ }^{2} \\
\text { Chiite }^{2} \\
\text { Sunnite }^{2}\end{array}$ & $\begin{array}{l}n=9 \\
n=28 \\
n=36\end{array}$ & $\begin{array}{r}0 \\
50 \\
25\end{array}$ & $\begin{array}{l}11 \\
11 \\
22\end{array}$ & $\begin{array}{r}56 \\
14 \\
0\end{array}$ & $\begin{array}{r}33 \\
0 \\
8\end{array}$ & $\begin{array}{l}0 \\
4 \\
8\end{array}$ & $\begin{array}{r}0 \\
21 \\
36\end{array}$ \\
\hline $\begin{array}{l}\text { Amenian }^{2} \\
\text { Maronite }^{2} \\
\text { Greek Orthodox } \\
\text { Greek Catholic } \\
\text { Syriac }^{2}\end{array}$ & $\begin{array}{l}n=12 \\
n=16 \\
n=8 \\
n=6 \\
n=6\end{array}$ & $\begin{array}{r}83 \\
0 \\
0 \\
0 \\
33\end{array}$ & $\begin{array}{r}0 \\
13 \\
25 \\
50 \\
67\end{array}$ & $\begin{array}{r}0 \\
6 \\
37 \\
0 \\
0\end{array}$ & $\begin{array}{r}0 \\
0 \\
13 \\
0 \\
0\end{array}$ & $\begin{array}{r}8 \\
6 \\
0 \\
17 \\
0\end{array}$ & $\begin{array}{r}8 \\
75 \\
25 \\
33 \\
0\end{array}$ \\
\hline
\end{tabular}

${ }^{1}$ Only one of the allele was counted in patients homozygous by descent. The E167D and F479L mutations were found in one patient showing the V726A/E167D/F479L genotype but alleles were not determined. The K695R was also found in one patient; ${ }^{2}$ Patients with parents of different origins are not shown 
association between the presence of a mutation at codon 694 and amyloidosis was statistically significant $(P<0.001)$. Patients with amyloidosis showed three genotypes: M 694V/M694V, M694V/M 694I and M694I/M694I (Table3).

Alleles in cis position were found in two patients: one was homozygous for the V726A-E148Q complex allele, and a second showed the V726A/E167D/F479L genotype but the alleles could not be determined.

\section{Discussion}

The MEFV gene assessment in the Lebanese population revealed the presence of mutations in communities that had never been reported before. At present, 18 religious communities compose the Lebanese population. The Sunnite, Chiite, Druze, Maronite, Greek orthodox, Greek catholic, Syriac and Armenian communities are numerically the most important. This heterogeneity has been the consequence of the situation of Lebanon as a crossroads between Asia, Africa, and Europe. In the first century AD, the greater part of the population was Syriac-speaking Christian, a part of whom followed the Greek rites in the fifth century. Next, a Maronite community moved from Syria to Lebanon. During the Arab conquests, a portion of the population was converted to Islam (Sunnites). In the seventh century, the Moslem Chiite branch took place and a Chiite population migrated to Lebanon. In the eleventh century, the Moslem Druze community was formed and a portion settled in the central Lebanese mountains. More recently, the Christian Syriac, Armenian, Assyrian and Chaldean communities were pushed into Lebanon following regional political difficulties. Other smaller groups, notably, Protestant, Jewish, and Alawit completed the Lebanese mosaic population.

We observed a heterogen eous mutation spectrum (Table2), whereas in other populations, notably, Jews, Armenians and Turks, usually one mutation predominates. ${ }^{5,6,8,14,17,21,26}$ Inter- estingly, mutations were detected in patients belonging to all Lebanese communities, particularly, Maronites, Chiites, the Greek orthodox, Greek catholic and Syriacs and the mutation spectra were different among these communities (Table2).

Sixteen patients tested negative, of whom six belonged to the homogeneous Maronite population, and showed typical clinical FMF features. The etiopathology in these patients could be attributed to several mechanisms, including:

(1) unknown common FMF mutation,

(2) a new familial periodic fever syndrome,

(3) hyperimmunoglobulinemia-D syndrome (HIDS), and

(4) TNF-receptor associated periodic syndrome (TRAPS).

Unfortunately, we could not test the first two hypotheses due to the refusal of informative families to participate in the study. The HIDS and TRAPS are less likely since the patients tested showed an IgD level lower than $100 \mathrm{U} / \mathrm{ml}$ and a recessive inheritance of the disease. Nevertheless, these two periodic fevers will be taken into consideration for further investigations.

The spectrum of mutated alleles also differed among the religious groups that have not been known to mix throughout history due to geographic isolation and social marriage customs. A founder effect and the homogeneity of these groups are most probably at the origin of a skewing toward one particular FMF mutation.

The preval ence of the M $694 \mathrm{~V}$ mutation among Armenians is in accordance with al ready published data. ${ }^{5,6}$ However, the frequencies in the Lebanese Druze group are different from those reported among non-Lebanese Druze, most probably due to the founder effect. In fact, the V726A, which is usually frequent in non-Lebanese Druzes, ${ }^{5,6,8}$ accounts for only $11 \%$ ( $1 / 9$ alleles) and the M694I accounts for $56 \%$ (5/9 alleles).

Table 3 The mean severity score and clinical feature frequencies in function of the genotype

\begin{tabular}{|c|c|c|c|c|c|c|}
\hline & & $\begin{array}{l}\text { Severity score } \\
\text { (mean) }\end{array}$ & $\begin{array}{l}\text { Thoracic pain } \\
n=43\end{array}$ & $\begin{array}{l}\text { Arthritis } \\
n=36\end{array}$ & $\begin{array}{l}\text { Skin } \\
n=8\end{array}$ & $\begin{array}{l}\text { Amyloidosis } \\
n=6\end{array}$ \\
\hline $\begin{array}{l}\text { M694V/M694V } \\
\text { V726A/V726A } \\
\text { M694I/M694I } \\
\text { E148Q/E148Q } \\
\text { M680I/M680I }\end{array}$ & $\begin{array}{l}n=10 \\
n=4 \\
n=4 \\
n=2 \\
n=1\end{array}$ & $\begin{array}{l}8 \\
5 \\
5 \\
5 \\
6\end{array}$ & $\begin{array}{l}5(50 \%) \\
3(75 \%) \\
2(50 \%) \\
2(100 \%) \\
1(100 \%)\end{array}$ & $\begin{array}{l}6(60 \%) \\
3(75 \%) \\
1(25 \%) \\
1(50 \%) \\
-\end{array}$ & $\begin{array}{l}2(20 \%) \\
1(25 \%) \\
- \\
- \\
-\end{array}$ & $\begin{array}{l}4(40 \%) \\
- \\
1(25 \%) \\
- \\
-\end{array}$ \\
\hline $\begin{array}{l}\text { M694V/V726A } \\
\text { M694V/M694I } \\
\text { M694V/M680I } \\
\text { V726A/M694I } \\
\text { V726A/E148Q } \\
\text { V726A/M680I } \\
\text { M694I/E148Q }\end{array}$ & $\begin{array}{l}n=8 \\
n=3 \\
n=2 \\
n=2 \\
n=1 \\
n=3 \\
n=2\end{array}$ & $\begin{array}{l}5 \\
7 \\
5 \\
5 \\
1 \\
3 \\
3\end{array}$ & $\begin{array}{l}7(87 \%) \\
3(100 \%) \\
1(50 \%) \\
2(100 \%) \\
1(100 \%) \\
2(67 \%) \\
1(50 \%)\end{array}$ & $\begin{array}{l}7(87 \%) \\
3(100 \%) \\
- \\
- \\
- \\
1(33 \%) \\
1(50 \%)\end{array}$ & $\begin{array}{l}1(25 \%) \\
- \\
- \\
- \\
- \\
- \\
-\end{array}$ & $\begin{array}{l}- \\
1(33 \%) \\
- \\
- \\
- \\
- \\
-\end{array}$ \\
\hline $\begin{array}{l}\text { M694V/- } \\
\text { V726A/- } \\
\text { E148Q/- } \\
\text { M680I/- }\end{array}$ & $\begin{array}{l}n=7 \\
n=9 \\
n=5 \\
n=1\end{array}$ & $\begin{array}{l}4 \\
3 \\
4 \\
5\end{array}$ & $\begin{array}{l}3(43 \%) \\
3(33 \%) \\
1(20 \%) \\
1(100 \%)\end{array}$ & $\begin{array}{l}4(57 \%) \\
1(11 \%) \\
2(40 \%) \\
-\end{array}$ & $\begin{array}{l}1(14 \%) \\
1(11 \%) \\
1(20 \%) \\
-\end{array}$ & $\begin{array}{l}- \\
- \\
- \\
-\end{array}$ \\
\hline$-1-$ & $\mathrm{n}=16$ & 4 & $5(31 \%)$ & $6(37 \%)$ & $1(6 \%)$ & - \\
\hline
\end{tabular}


The presence of FMF patients in many different homoge neous Lebanese groups parallels the presence of patients in different Mediterranean populations. Although we have not conducted yet a study to determine the FMF carrier frequency in the Lebanese population, the present heterogeneous cohort of patients re-emphasis the hypothesis of a selective advantage for the FMF carrier chromosomes in the Mediterranean region.

Assessment of the phenotype-genotype correlation revealed that the Armenian, Chiite and Druze groups showed the highest severity scores and frequencies of M694V or M 694I mutations (Table2), and that patients with amyloidosis belong exclusively to these three communities. In parallel, all patients with amyloidosis carry two mutations in codon 694 of exon 10 (four M694V homozygous, one M694I homozygous and one M 694V/M 694I heterozygous) (Table3). It is noteworthy that these patients had never received colchicine treatment. The statistical analysis showed that the association between the presence of mutations at codon 694 in exon 10 and amyloidosis is the only significant correlation $(P<0.001)$ in the present cohort.

Two patients aged 43 and 60 who have never been treated with colchicine and have not developed amyloidosis showed the M694V/M694V and M694I/M 694I genotypes, respectively. Neither patients reported positive FMF family history or consanguinity, whereas all the other patients with amyloidosis reported positive family history and/or consanguinity. These two cases suggest that, in addition to the MEFV mutations, there exists a second genetic factor that predisposes to the development of amyloidosis.

In conclusion, this study allowed us to detect MEFV gene mutations in the Maronite, Greek orthodox, Greek catholic, Syriac and Chiite communities and to establish the mutation spectrum among the Lebanese FMF patients. The most important features are the heterogeneity of mutations and the high number of chromosomes who tested negative for all the mutations. This provides important tools for adapting a molecular diagnostic test for the Lebanese population and further investigations. The genotype-phenotype analysis also indicates that both M694V and M694I mutations are associated with amyloidosis.

\section{Acknowledgements}

We are very indebted to families, physicians, Pr Jean-Claude Lecron and $\operatorname{Pr}$ Jean-Louis Preud'Homme who made this study possible and to the Conseil de la Recherche Scientifique de I'Université Saint Joseph, Beyrouth for its financial support.

\section{References}

1 Pras M: Familial Mediterranean Fever: from the clinical syndrome to the cloning of the pyrin gene. Scand J Rheumatol 1998; 27: 92-97.

2 Ben-Chetrit E, Levy M: Familial Mediterranean fever. Lancet 1998; 351: 659-664.

3 Samuels J, Aksentijevich I, Torosyan $Y$ et al: Familial Mediterranean Fever at the Millennium. Clinical spectrum, ancient mutations, and survey of 100 American referrals to the National Institutes of Health. Rev Mol Med 1998; 77: 268-297.
4 Sohar E, Gafni J, Pras M, Heller H: Familial Mediterranean Fever. A survey of 470 cases and review of the literature. Am J Med 1967; 43: 227-253.

5 The International FMF Consortium: Ancient missense mutations in a new member of the RoRet Gene family are likely to cause Familial Mediterranean Fever. Cell 1997; 90: 797-807.

6 The French FMF Consortium: A candidate gene for familial Mediterranean fever. Nat Genet 1997; 17: 25-31.

7 Pras M: Clinical differences between North African and Iraqi Jews with FMF. Am J Med Genet 1998; 75: 216-219.

8 Touitou I, Ben-Chetrit E, Notrnicola C et al: Familial Mediterranean Fever Clinical and Genetic features in Druzes and in Iraqi Jews: A preliminary study. J Rhum 1998; 25: 916-919.

9 Rawashdeh MO, Majeed HA: Familial Mediterranean Fever in Arab children: the high prevalence and gene frequency. Eur Pediatr 1996; 155: 540-544.

10 Schwabe AD, Peters RS: FMF in Armenians. Analysis of 100 cases. Medecine 1974; 53: 453-462.

11 Sohar E, Gafni J, Pras M, Heller H: FMF: A survey of 470 cases and review of the literature. Am J Med 1967; 43: 227-253.

12 Reimann HA, Moadié J, Semerdjian S, Shyoun P: Periodic peritonitis-heredity and pathology. JAM A 1954; 154: 1254-1259.

13 Bernot A, da Silva C, Petit JL et al: Non-founder mutations in the MEFV gene establish this gene as the cause of familial Mediterranean fever (FMF). Hum Mol Genet 1998; 8: 1317-1325.

14 Chen X, Fischel-Ghodsian N, Cercek A, Hamon M, Ogur G, Lotan $\mathrm{R}$, Danon $\mathrm{Y}$, Shohat $\mathrm{M}$ : Assessment of Pyrin gene mutations in Turks with familial Mediterranean fever (FMF). Hum Mut 1998; 11: 456-460.

15 Yalçinkaya F, Akar N, Misirlioglu M: Familial Mediterranean feveramyloidosis and the Val726Ala mutation. N Engl J Med 1998; 338 : 993-994.

16 Aksentijevich I, Torosyan Y, Samuels J et al: Mutation and Haplotype studies of Familial Mediterranean Fever reveal new ancestral relationships and evidence for a high carrier frequency with reduced penetrance in the Ashkenazi Jewish population. Am J Hum Genet 1999; 64: 949-962.

17 Cazeneuve C, Sarkisian T, Pêcheux Ch et al: MEFV-Gene analysis in Armenian patients with Familial Mediterranean Fever: Diagnostic value and unfavourable renal prognosis of the M694V homozygous genotype-Genetic and therapeutic implications. Am J Hum Genet 1999; 65: 88-97.

18 Dodé $C$, Pêcheux Ch, Cazeneuve $C$ et al: Mutations in the MEFV gene in a large series of patients with clinical diagnosis of familial Mediterranean fever. Am J Med Genet 2000; 92: 241-246.

19 Press J, Shinar Y, Langevitz P, Livneh A, Pras M, Buskila D: Familial Mediterranean fever in two Bedouin families: Mutation analysis and disease severity. Am J Med Genet 2000; 92: 247-249.

20 Booth DR, Gillmore JD, Booth SE, Pepys MB, Hawkins PN: Pyrin/ marenostrin mutations in familial Mediterranean fever. Q J Med 1998; 91: 603-606.

21 Dewalle M, Domingo C, Rozenbaum M et al: Genotype-phenotype correlation in Jewish patients suffering from familial Mediterranean fever (FMF). Eur J Hum Genet 1998; 6: 95-97.

22 Livneh A, Langevitz $P$, Zemer $D$ et al: Criteria for the diagnosis of Familial Mediterranean Fever. Arthritis and Rheumatism. 1997; 10: $1879-1885$

23 Sohar E, Gafni J, Pras M, Freund (eds): Proceedings 1st International Conference on FMF, Jerusalem. 1997, pp 207-208.

24 International study group for Behçet's Disease: Criteria for diagnosis of Behçet's Disease. The Lancet 1990; 335: 1078-1080.

25 Levan-Petit I, Cardonna J, Garcia M et al: A sensitive ELISA for human IgD measurement in neonate, infant and adult sera and lymphocyte culture superatnants. Clin Chem 2000; 46: 876-878.

26 Shohat M, Magal N, Shohat T et al: Phenotype-genotype correlation in familial Mediterranean fever: evidence for an association between Met694Val and amyloidosis. Eur J Hum Genet 1999; 7: 287-292. 